\title{
Characterisation of the Contaminants Generated from a Large-Scale Ex-Situ Underground Coal Gasification Study Using High-Rank Coal from the South Wales Coalfield
}

\author{
Sivachidambaram Sadasivam (D) - Renato Zagorščak • \\ Hywel Rhys Thomas • Krzysztof Kapusta $\cdot$ Krzysztof \\ Stańczyk
}

Received: 14 May 2020 / Accepted: 24 September 2020 / Published online: 5 October 2020

(C) The Author(s) 2020

\begin{abstract}
This paper presents an analysis of contaminants generated from large-scale, laboratory-based, underground coal gasification (UCG) experiments using a high-rank coal from the South Wales Coalfield. The experiments were performed at atmospheric and elevated pressures (30 bar) by varying the oxidants' composition. The experiments were designed to predict the amount of produced water and contaminants generated at each stage of the operating conditions. The mass balance of water supplied and produced in the experiments was accounted for. Chemical analyses of produced water, char and ash contents were performed to quantify the inorganic and organic chemical parameters. Most of the contaminant concentrations in the produced water from the 30-bar pressure experiment were lower than the concentrations generated from the atmospheric pressure experiment. The measured concentrations of the inorganic chemical species and the inorganic parameters of the coal seam water from the South Wales Coalfield were used in theoretical calculations to predict
\end{abstract}

Electronic supplementary material The online version of this article (https://doi.org/10.1007/s11270-020-04888-1) contains supplementary material, which is available to authorized users.

S. Sadasivam $(\bowtie) \cdot$ R. Zagorščak $\cdot H$. R. Thomas Geoenvironmental Research Centre (GRC), School of Engineering, Cardiff University, The Queen's Buildings, The Parade, Cardiff CF24 3AA, UK

e-mail: sadasivams@ cardiff.ac.uk

K. Kapusta • K. Stańczyk

Główny Instytut Górnictwa (Central Mining Institute), Plac Gwarków 1, 40-166 Katowice, Poland the dominant equilibrium species concentrations in a hypothetical scenario of effluent contaminated groundwater. The biodegradation of organic contaminants such as phenol, benzene and sorbed fractions of inorganic contaminants from the produced water on iron oxide in the ash residue was predicted using existing biotransformation kinetics and surface complexation models, respectively. The biodegradation of phenol and benzene would be a slow process even at optimum conditions and the iron oxide left in the cavity can act as a sorbent for a few inorganic species. The evidence from the present study suggests future work towards (i) developing an appropriate water treatment process during gas cleaning, (ii) operational procedure (pressure and proportions of oxidant) and (iii) developing UCG-specific experimental prediction of contaminant transportation and transformation kinetics.

Keywords High-rank coal · Underground coal gasification · High pressure $\cdot$ Produced water - Inorganic organic contaminants $\cdot$ Ash

\section{Introduction}

Underground coal gasification (UCG) is a process through which gasification of coal is carried out underground within geological strata. It is similar to surface gasification, but the air, oxygen and steam are injected through boreholes to gasify the coal and the produced gas is recovered through a production well. UCG is gaining attention in many countries due to the economic 
and processing benefits. However, gasification of coal underground may pose a threat to groundwater. Also, treatment and disposal of effluent generated during the gas cleaning process needs to be considered. Gasification releases organic contaminants such as phenol, benzene, toluene, ethyl benzene, xylene (BTEX) and polycyclic aromatic hydrocarbons (PAH) along with inorganic metals, metalloids, non-metal and anionic compounds.

Many previous studies have been carried out to qualitatively and quantitatively measure the amount and type of contaminants produced from various coal samples (Campbell et al. 1979; Liu et al. 2007; Kapusta and Stańczyk 2011; Kapusta et al. 2013). The present work focuses on contaminants generated from a high-rank coal from the South Wales Coalfield (UK) to study the possible environmental impact of conducting UCG in geological settings hosting carbon-rich coals.

Groundwater pollution is considered to be the most serious possible negative environmental impact of UCG. It can be caused by gases escaping from the reactor through fractures and condensing in the cooler parts of the subsurface and then dissolving in groundwater (Stephens 1981; Wang et al. 1982; Dames and Moore 1996; Humenick and Novak 1978). Hence, there is a need to study contaminant generation at varying experimental conditions. Early UCG trials at Hoe Creek (Humenick and Mattox 1978) and European pilot plant studies (Creedy et al. 2001) provide limited information in the context of operational procedures related to contaminant generation. A monitoring programme at an UCG trial site in Australia reported contaminants measured in soil vapour and groundwater. Although there were significant reductions in the contaminations over the years after the site was closed, reports generated during the monitoring showed evidence for the contaminants' dispersion to the subsurface and identified unexpected levels of hydrogen in the top soils of the adjacent farm fields (Australian governments environmental protection order 2016; Gemmell 2016). This indicates the possibility of gas escape to the subsurface. The operational procedures of the Australian example, which was performed at shallow depth $(200 \mathrm{~m})$, were unknown and the example does not provide a way forward. It is assumed the UCG operations were carried out at lower pressure than the hydrostatic pressures of the surrounding strata to avoid the contaminants escape (Blinderman and Jones 2002). Despite following the best process practices, some concentrations of pollutants in groundwater have been reported (Gemmell 2016). It should be noted that the process was conducted at a relatively shallow depth $(<150 \mathrm{~m})$, and the probability of groundwater contamination decreases with increasing depth of UCG.

The deepest known operation so far was Swan Hills $(1400 \mathrm{~m})$ trial but offers limited or no information on quantitative/qualitative measurement of groundwater or produced water quality and baseline environmental site characterisation (Swan Hills Synfuels 2012; AER 2014).The deep coal seam operations at El Tremedal, Spain $(550 \mathrm{~m})$, showed no impact on the groundwaters. However, the water ingression to the cavity was an issue at El Tremedal, which generated wastewater with considerable amounts of phenols, ammonia, sulphurs and conductivity, and COD and was characterised as toxic water (Sury et al. 2004). Hence, it is necessary to monitor the produced water and groundwater, and the current study is intended to study the produced water constitutions and predict the impact on an existing coal seam groundwater from $600 \mathrm{~m}$ depth.

Groundwater pollution studies were conducted during a UCG trial at mine Barbara, Poland, where the contaminants were monitored during the gasification process and after gasification for 200 days (Kapusta et al. 2013). A short-range and short-term impact of the UCG trial on groundwater was observed. Highly water-soluble specimens, including phenols, ammonia, cyanides and selected metal ions, were the dominant and the most mobile pollutants. It was also assumed that the possibility of naturally occurring self-restoration processes through dispersion, adsorption and degradation of the organic contaminants were the reasons for the decreasing level of contaminants measured over the monitoring period. Not only the escaping contaminants from the cavity pose a threat to groundwater but the solid ash, char and tar left in the cavity would also be leached out by the groundwater (Kapusta et al. 2013; Covell and Thomas 1996).

There are discussions to utilise un-minable coal through UCG (Geology and Regional Geophysics Commissioned Report 2013), but the technological aspects and environmental impact of performing UCG on a regional geological setting are unknown. The present study explores first-hand information on contaminants generated by a high-rank coal sample from the South Wales Coalfield in a large-scale ex situ UCG experiment. The inorganic contaminants are equilibrated with coal seam water from the South Wales Coalfield to 
understand the dominant species concentrations. The study also discusses the possible scenario of the postUCG natural restoration process by biodegradation of organic contaminants such as phenol and benzene.

\section{Materials and Methods}

\subsection{Experimental Aspects of Ex Situ UCG Test}

Table 1 shows the results of proximate, ultimate and petrographic composition analyses of the coal specimen which indicates that the coal sample can be classified as high-rank semi-anthracite (ASTM D388-18a, 2018, ASTM D7582-15, 2015, ASTM D3176-15, 2015).

The laboratory-scale UCG simulations were conducted at large-scale laboratory facilities of the Central Mining Institute's Clean Coal Technology Centre located in Mikołów, Poland. The experimental set up was as described in Kapusta and Stańczyk (2011), Wiatowski et al. (2019) and Zagorščak et al. (2020) (Fig. 1). Two artificial coal seams $($ size $=3.05 \mathrm{~m} \times 0.41 \mathrm{~m} \times 0.41 \mathrm{~m}$, mass $=$ $648 \mathrm{~kg}$ (atmospheric test) and $650 \mathrm{~kg}$ (30 bar pressure test) were prepared using 5 blocks of coal (Zagorščak et al. 2020). Two separate gasification experiments, one at atmospheric pressure and other at 30 bar pressure, were performed. Each experiment consisted of 6 gasification stages and one extinguishing stage. During the gasification stages, the following reagents were used: oxygen, air and oxygen enriched ear (OEA). In the extinguishing stage, nitrogen was used as inertising medium. Water was supplied to the reactor by means of a high-pressure piston pump, while its quantity was measured with a water meter installed in front of the pump (accuracy \pm $2 \%$ ). Gases were supplied from gas cylinders using mass flow controllers (MFC) with accuracy of $\pm 2 \%$. The UCG simulation experiments were conducted for $105 \mathrm{~h}$ each. The experimental conditions, including the reagent supply rates, in different stages of the atmospheric and highpressure UCG experiments are presented in Table 2. The detailed interpretation of the experimental results is presented in Zagorščak et al. (2020).

Table 1 Properties of coal and char specimens

\begin{tabular}{|c|c|c|c|c|c|c|c|c|}
\hline \multirow[t]{3}{*}{ No. } & \multirow[t]{2}{*}{ Parameter/sample } & \multirow[t]{3}{*}{ Coal } & \multicolumn{3}{|c|}{ Atmospheric pressure } & \multicolumn{3}{|l|}{30 bar } \\
\hline & & & \multicolumn{3}{|c|}{ Char (distance from inlet) } & \multicolumn{3}{|c|}{ Char (distance from inlet) } \\
\hline & As received & & $1 \mathrm{~m}$ & $2 \mathrm{~m}$ & $3 \mathrm{~m}$ & $1 \mathrm{~m}$ & $2 \mathrm{~m}$ & $3 \mathrm{~m}$ \\
\hline 1 & Total moisture, $\%$ & $1.15 \pm 0.40$ & $0.24 \pm 0.30$ & $0.04 \pm 0.30$ & $0.85 \pm 0.30$ & $1.05 \pm 0.16$ & $1.16 \pm 0.15$ & $0.93 \pm 0.15$ \\
\hline 2 & Ash, $\%$ & $4.61 \pm 0.30$ & $16.34 \pm 0.44$ & $11.34 \pm 0.30$ & $4.71 \pm 0.30$ & $4.46 \pm 0.32$ & $5.39 \pm 0.38$ & $4.84 \pm 0.35$ \\
\hline 3 & Volatiles, $\%$ & $9.92 \pm 0.12$ & $0.21 \pm 0.01$ & $0.27 \pm 0.01$ & $0.40 \pm 0.02$ & $0.84 \pm 0.17$ & $0.57 \pm 0.16$ & $1.04 \pm 0.18$ \\
\hline 4 & Total sulphur, $\%$ & $1.55 \pm 0.04$ & $1.97 \pm 0.04$ & $1.96 \pm 0.04$ & $1.27 \pm 0.04$ & $1.14 \pm 0.08$ & $1.19 \pm 0.08$ & $0.99 \pm 0.08$ \\
\hline 5 & $\begin{array}{l}\text { Calorific value, } \mathrm{kJ} / \mathrm{kg} \\
\text { Analytical }\end{array}$ & $33,416 \pm 220$ & $27,605 \pm 184$ & $29,470 \pm 196$ & $31,688 \pm 210$ & $32,050 \pm 170$ & $31,921 \pm 170$ & $32,361 \pm 173$ \\
\hline 6 & Moisture, \% & $0.84 \pm 0.30$ & $0.24 \pm 0.30$ & $0.04 \pm 0.30$ & $0.85 \pm 0.30$ & $1.05 \pm 0.16$ & $1.16 \pm 0.15$ & $0.93 \pm 0.15$ \\
\hline 7 & Ash, $\%$ & $4.62 \pm 0.30$ & $16.34 \pm 0.44$ & $11.34 \pm 0.30$ & $4.71 \pm 0.30$ & $4.46 \pm 0.32$ & $5.39 \pm 0.38$ & $4.84 \pm 0.35$ \\
\hline 8 & Volatiles, \% & $9.95 \pm 0.13$ & $0.21 \pm 0.01$ & $0.27 \pm 0.01$ & $0.40 \pm 0.02$ & $0.84 \pm 0.17$ & $0.57 \pm 0.16$ & $1.04 \pm 0.18$ \\
\hline 9 & $\begin{array}{l}\text { Heat of } \\
\quad \text { combustion, } \mathrm{kJ} / \mathrm{kg}\end{array}$ & $34,414 \pm 228$ & $27,611 \pm 184$ & $29,471 \pm 196$ & $31,790 \pm 211$ & $32,294 \pm 172$ & $32,141 \pm 171$ & $32,668 \pm 173$ \\
\hline 10 & Calorific value, $\mathrm{kJ} / \mathrm{kg}$ & $33,527 \pm 221$ & $27,605 \pm 184$ & $29,470 \pm 196$ & $31,688 \pm 210$ & $32,050 \pm 170$ & $31,921 \pm 170$ & $32,361 \pm 173$ \\
\hline 11 & Total sulphur, \% & $1.55 \pm 0.04$ & $1.97 \pm 0.04$ & $1.96 \pm 0.04$ & $1.27 \pm 0.04$ & $1.14 \pm 0.08$ & $1.19 \pm 0.08$ & $0.99 \pm 0.08$ \\
\hline 12 & Carbon, $\%$ & $87.31 \pm 0.66$ & $80.28 \pm 0.66$ & $86.70 \pm 0.66$ & $92.17 \pm 0.66$ & $90.62 \pm 1.13$ & $90.06 \pm 1.13$ & $90.44 \pm 1.13$ \\
\hline 13 & Hydrogen, $\%$ & $3.97 \pm 0.28$ & $0.00 \pm 0.01$ & $0.00 \pm 0.01$ & $0.37 \pm 0.20$ & $1.00 \pm 0.40$ & $0.88 \pm 0.40$ & $1.30 \pm 0.40$ \\
\hline 14 & Nitrogen, $\%$ & $1.29 \pm 0.12$ & $0.75 \pm 0.14$ & $0.68 \pm 0.14$ & $1.08 \pm 0.12$ & $1.20 \pm 0.22$ & $1.17 \pm 0.22$ & $1.23 \pm 0.22$ \\
\hline 15 & Oxygen, \% & $0.50 \pm 0.05$ & $0.51 \pm 0.10$ & $0.58 \pm 0.12$ & $0.45 \pm 0.09$ & $0.59 \pm 0.12$ & $0.26 \pm 0.05$ & $0.52 \pm 0.10$ \\
\hline 16 & Specific gravity & $1.35 \pm 0.028$ & $1.86 \pm 0.048$ & $1.814 \pm 0.046$ & $1.736 \pm 0.044$ & $1.662 \pm 0.015$ & $1.752 \pm 0.015$ & $1.707 \pm 0.015$ \\
\hline 17 & $\begin{array}{l}\text { Vitrinite } \\
\quad \text { Reflectance, } \mathrm{R}_{0}, \%\end{array}$ & & $7.03 \pm 0.13$ & $7.10 \pm 0.13$ & $6.44 \pm 0.12$ & $5.16 \pm 0.13$ & $4.72 \pm 0.12$ & $4.20 \pm 0.10$ \\
\hline
\end{tabular}




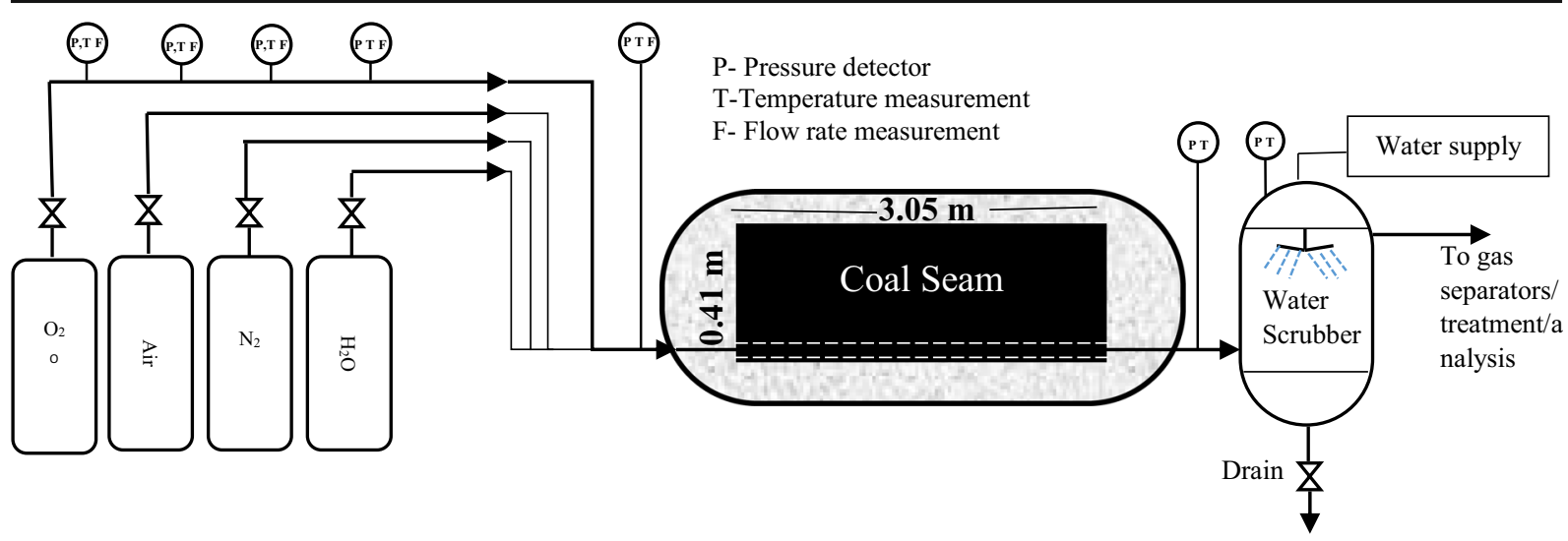

Fig. 1 Schematic of the installation of UCG simulation experiment

The UCG effluents were periodically sampled during the gasification tests from the water scrubber (see Fig. 1). The scrubber was employed to quench and clean the raw UCG gas. The water was supplied to the scrubber, at a rate of $18 \mathrm{~kg} / \mathrm{h}$. The amount of water supplied into the scrubber and the amount of water supplied into the reactor during each stage of the experiments were accounted for in the water mass balance and presented in Table 2. The total quantities of produced effluents depend on the amount of water used in the scrubber, water supplied as the gasification reagent, pyrolytic water generated in the pyrolysis zone of the reactor and water produced via combustion of hydrogen. The amounts of produced water condensates were determined by the weight method with an accuracy of $\pm 2 \mathrm{~kg}$. The effluents from stage 1 and stage 2 were collected separately and labelled S1 and S2, respectively. The effluents produced at stage 3 to stage 6 were averaged together, labelled as 'S3 to S6' for the atmospheric test and analysed as a one sample. Similarly, the effluents collected from the highpressure test were labelled as $30 \mathrm{~S} 1,30 \mathrm{~S} 2$ and ' $30 \mathrm{~S} 3$ to 30S6'. The collected water samples were filtered to remove the coal tar and undissolved residues and stored at $4{ }^{\circ} \mathrm{C}$ until chemical characterisation was conducted. The solid residues from the gasification were collected at the end of the experiments for inorganic chemical analysis.

Chemical analyses of the UCG produced water were performed as described in the standard analytical chemistry methods. Electrochemical methods such as potentiometry and conductometry were employed to determine the $\mathrm{pH}$ and the conductivity of produced water, respectively. The biological oxygen demand (BOD) and chemical oxygen demand (COD) were determined following the procedures described in PNEN-1899-1: 2002, PN-EN-1899-2 2002 (BOD) and PNISO 15705: 2005 (COD), respectively. Total ammonia nitrogen content was characterised by flow-injection analysis (FIA) with gaseous diffusion and spectrophotometric detection (light absorption at the wavelength of $590 \mathrm{~nm}$ ) method (PN-EN ISO 11732: 2007). Silver nitrate titration method was used to measure the amount of chloride. The cyanides were measured by employing segmented flow analysis (SFA) with spectrophotometric detection as described in PN-EN ISO 14403: 2004 and PN-EN ISO 14402: 2004, respectively. A gravimetric method (barium precipitation) was used in the quantification of sulphates. Elemental quantitative analysis of 17 metals and metalloids were performed by inductively coupled plasma - optical emission spectroscopy (ICPOES) (PN-EN ISO 11885: 2009). The 15 polycyclic aromatic hydrocarbons (PAHs) were determined using solid-phase extraction (SPE) on ENVI-C18 cartridges purchased from Supelco (St Louis, MO, USA) followed by high-performance liquid chromatography (HPLC) using an Agilent Technologies HPLC 1200 Series. An Agilent Technologies 7890A gas chromatography coupled with a static headspace auto sampler Agilent 7697A and FID detector was used to measure the benzene and its derivatives (BTEX). The gas chromatography was configured with a DB-5MS column $(30 \mathrm{~m}$, $0.25 \mathrm{~mm}, 0.5 \mu \mathrm{m}$ ) and helium was used as the carrier gas at $1.0 \mathrm{ml} / \mathrm{min}$. The split ratio was $1: 30$. Oven program temperature was $40{ }^{\circ} \mathrm{C}$ (hold $3 \mathrm{~min}$ ), rate $15^{\circ} \mathrm{C} / \mathrm{min}$ up to $200{ }^{\circ} \mathrm{C}$ (hold $9 \mathrm{~min}$ ). Temperature of FID detector was $300^{\circ} \mathrm{C}$. The post gasification residues (char and ash) were collected at different locations in the reactor. The post gasification ash specimen was 


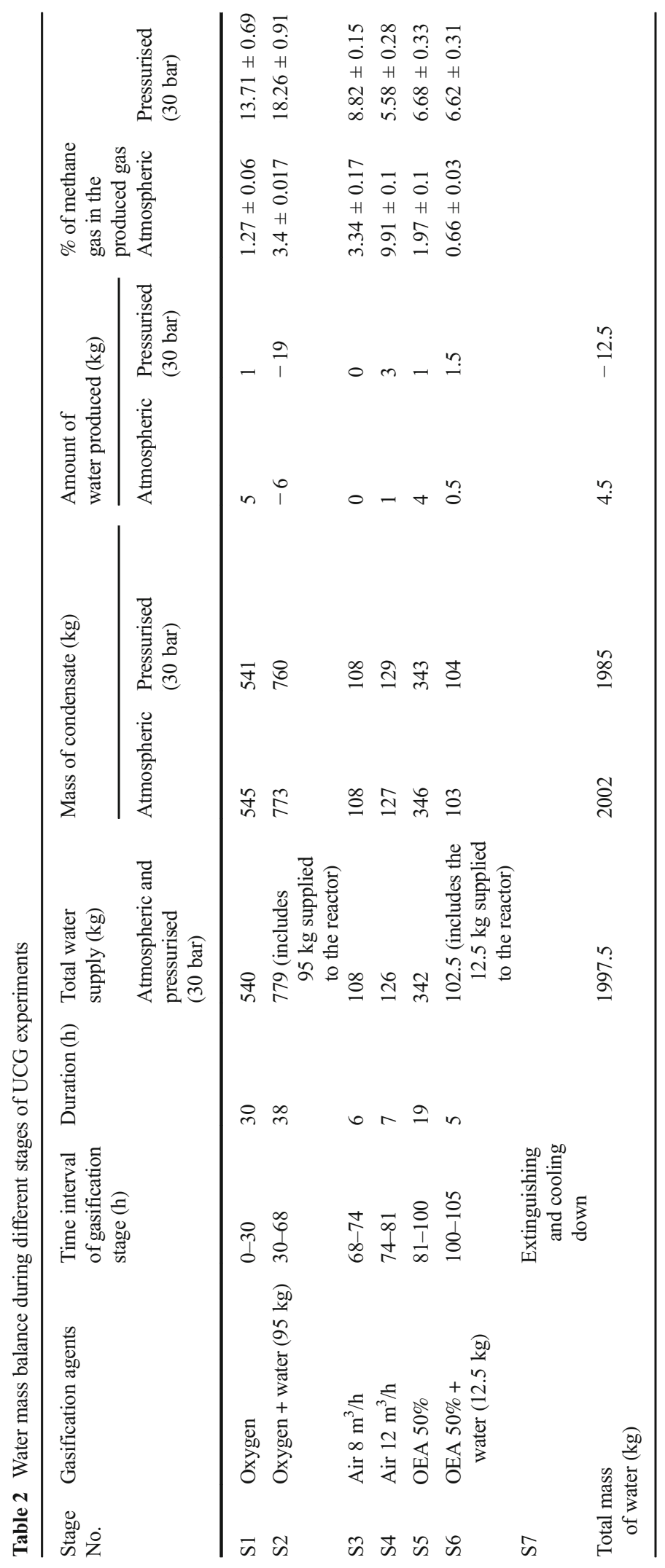


collected at approximately $0.4 \mathrm{~m}$ from the inlet. The char specimens were collected at approximately $1 \mathrm{~m}$, $2 \mathrm{~m}$ and $3 \mathrm{~m}$ (Fig. 2c). The major and minor elemental composition analysis was carried out as per the procedure described in ISO/TS 13605: 2012 using an X-ray fluorescence spectrometry.

\subsection{Analysis of Produced Water Using Geochemist's Work Bench (GWB)}

Geochemist's work bench (GWB), a computer application software, was used to analyse equilibrium species concentration, Monod degradation kinetics of organic contaminants and sorbed fractions of chemical species on iron oxide surface (Bethke 2007). The GWB application was employed in the study to predict the equilibrium species and trace the biodegradation reactions that happen immediately after the contaminants contact with groundwater. (i) Inorganic chemical species in produced watergroundwater system: The measured concentrations from the produced water ( $\mathrm{C} 1$ from Table 3$)$ and the groundwater matrix procured from a coal seam located at $600 \mathrm{~m}$ depth in the South Wales Coalfield were used to describe the theoretical composition of contaminated groundwater. The major ions in the coal seam aquifer; $\mathrm{Na}=540 \mathrm{mg} / \mathrm{L}$, $\mathrm{K}=10.03 \mathrm{mg} / \mathrm{L}, \mathrm{Mg}=1.29 \mathrm{mg} / \mathrm{L}$ and $\mathrm{Ca}=$ $2.87 \mathrm{mg} / \mathrm{L}$ and dissolved oxygen $=2.25 \mathrm{mg} / \mathrm{L}$ (Sadasivam et al. 2019) and the contaminant concentrations in the sample $\mathrm{C} 1$ were assumed to be in $1 \mathrm{~kg}$ of groundwater. The React programme from GWB was used to input the above concentrations and set the temperature constrain at $20{ }^{\circ} \mathrm{C}$, as the temperature range of the coal seam water was 20 $22{ }^{\circ} \mathrm{C}$ around $600 \mathrm{~m}$ depth. The programme was run at different $\mathrm{pH}$ values using the 'slide $\mathrm{pH}$ ' option of React programme to predict the equilibrium species.
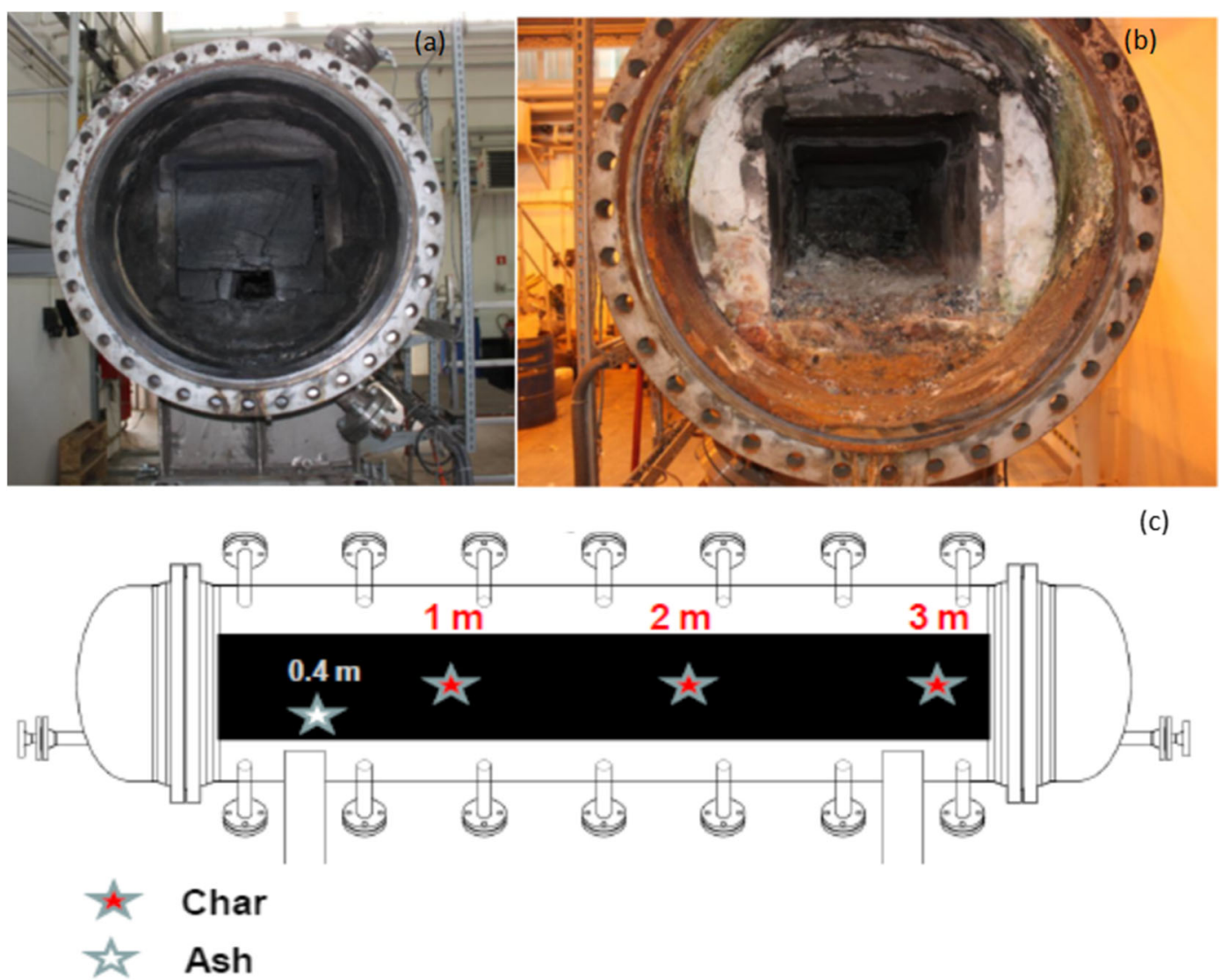

Fig. 2 Images of coal seam after the experiment a outlet view (char), b inlet and $\mathbf{c}$ locations of the ash, char specimen collected 
(ii) Sorbed species on iron oxide surfaces: The ash produced in the cavity consist of $18 \% \mathrm{Fe}$ and considering the temperature exposure and oxygen availability, the iron must be in haematite form. In the event of cavity flooding, the haematite in the ash reacts with the groundwater. The iron oxide left in the cavity could retain the inorganic species by surface complexation. In the calculations, it is assumed that $5 \mathrm{~g}$ of haematite is dispersed in $1 \mathrm{~kg}$ of UCG contaminant laden groundwater $(\mathrm{C} 1+$ coal seam water from Section 2.2 (i)). Data file $\mathrm{FeOH}+$ dat from GWB dataset, which includes the surface complexation reaction dataset (Dzombak and Morel 1990), was used in the React programme to predict the sorbed fractions of the species of $\mathrm{As}, \mathrm{B}, \mathrm{Co}, \mathrm{Cr}, \mathrm{Cu}, \mathrm{Ni}, \mathrm{Pb}$ and $\mathrm{Se}$ at varying $\mathrm{pH}$ values. Surface complexation model was used in the study as the theory includes electrolytic sorption, hydrolysis, the mineral surface, electric charge on the surface and mass balance unlike the distribution coefficient $\left(k_{\mathrm{d}}\right)$ and Freundlich approach which predict that the surface can adsorb without limits.

(iii) Biodegradation of phenol and benzene: the concentrations of inorganic constitutions from sample C1 (Table 3), phenol and benzene concentrations from C3 (Table 7) were used in the description of $1 \mathrm{~kg}$ mass of hypothetical water in the React programme. The benzene and phenol degradation by microorganisms with sufficient nutrition can be represented by reactions; [1] $\mathrm{C}_{6} \mathrm{H}_{6}$ (aq) $+3 \mathrm{H}_{2} \mathrm{O}$ $+7.5 \mathrm{O}_{2} \rightarrow 6 \mathrm{HCO}_{3}^{-}+6 \mathrm{H}^{+}$for benzene and [2] $\mathrm{C}_{6} \mathrm{H}_{5} \mathrm{OH}_{(\mathrm{aq})}+\frac{13}{2} \mathrm{H}_{2} \mathrm{O} \rightarrow \frac{7}{2} \mathrm{CH}_{4}(\mathrm{aq})+\frac{5}{2} \mathrm{HCO}_{3}^{-}$ $+\frac{5}{2} \mathrm{H}^{+}$for phenol. The Monod kinetic parameters published in Alvarez et al. (1991) and Appelo and Postma (1993) were used to trace the biodegradation process of benzene and phenol.

\section{Results and Discussion}

\subsection{Water Balance during the UCG Experiments}

The amount of water fed into the system was compared with the water collected from the condensation. The raw UCG gas contains water vapour which is loaded with inorganic and organic contaminants. The water vapour condensates along with the contaminants in the cooler parts of the UCG installation. Monitoring the water balance gives insight into the amount of water produced at various stages of gasification and the overall impact on the groundwater environment and the process to treat the water used for cleaning the gas. The total mass of water supplied to the reactor was $107.5 \mathrm{~kg}$ (95 kg at stage 2 and $12.5 \mathrm{~kg}$ at stage 6). The mass of water supplied to the scrubber was $1890 \mathrm{~kg}$ during the entire process. Hence, the total mass of water used in each experiment was $1997.5 \mathrm{~kg}$. The masses of water collected from the condenser during the atmospheric and 30 bar pressure experiments were $2002 \mathrm{~kg}$ and $1985 \mathrm{~kg}$, respectively. Considering the $\pm 2 \mathrm{~kg}$ of measurement error, the overall water mass balances were retained during the gasification experiments. The negative values in stage 2 (S2-oxygen/water) for both experiments (Table 2) resulted from water consumption in the gasification process. The water consumption at this stage (S2) supported more methane producing reactions where oxygen and steam were used as oxidants.

\subsection{Inorganic Parameters of UCG Produced Water and Ash}

The results from the analysis show that the values of measured physicochemical parameters significantly varied over the time in the experiments. These variations reflected changes in the gasification conditions (temperature) and development of oxidation and pyrolysis zones during the experiments. There were considerable differences between the contaminant concentrations generated during the atmospheric and 30 bar pressure conditions (Table 3 ). The average $\mathrm{pH}$ of condensate collected during the experiment conducted under atmospheric pressure conditions was around 7 . The produced water collected during the pressurised experiments showed $\mathrm{pH}$ ranging from acidic $(\mathrm{pH}=4.6,30 \mathrm{~S} 1$, Table 3 ) to alkaline ( $\mathrm{pH}=8.3,30 \mathrm{~S} 3$ to $30 \mathrm{~S} 6$, Table 3 ). The electric conductivities measured during the atmospheric conditions $(3.63 \mathrm{mS} / \mathrm{cm}$ to $8.9 \mathrm{mS} / \mathrm{cm}$ ) were higher than during the pressurised conditions $(1.02 \mathrm{mS} / \mathrm{cm}$ to $2.76 \mathrm{mS} / \mathrm{cm})$. The electric conductivity of the condensates has been reported as high as $19.2 \mathrm{mS} /$ cm (Kapusta and Stańczyk 2011). The produced water generated during the high pressure (30 bar) experiment exhibited comparatively lower concentrations of COD, $\mathrm{B}, \mathrm{Ni}, \mathrm{As}, \mathrm{Cl}^{-}, \mathrm{NH}_{3}(\mathrm{aq}), \mathrm{SO}_{4}{ }^{2-}$ and $\mathrm{CN}^{-}$than during the atmospheric conditions. The varying $\mathrm{pH}$ of the 


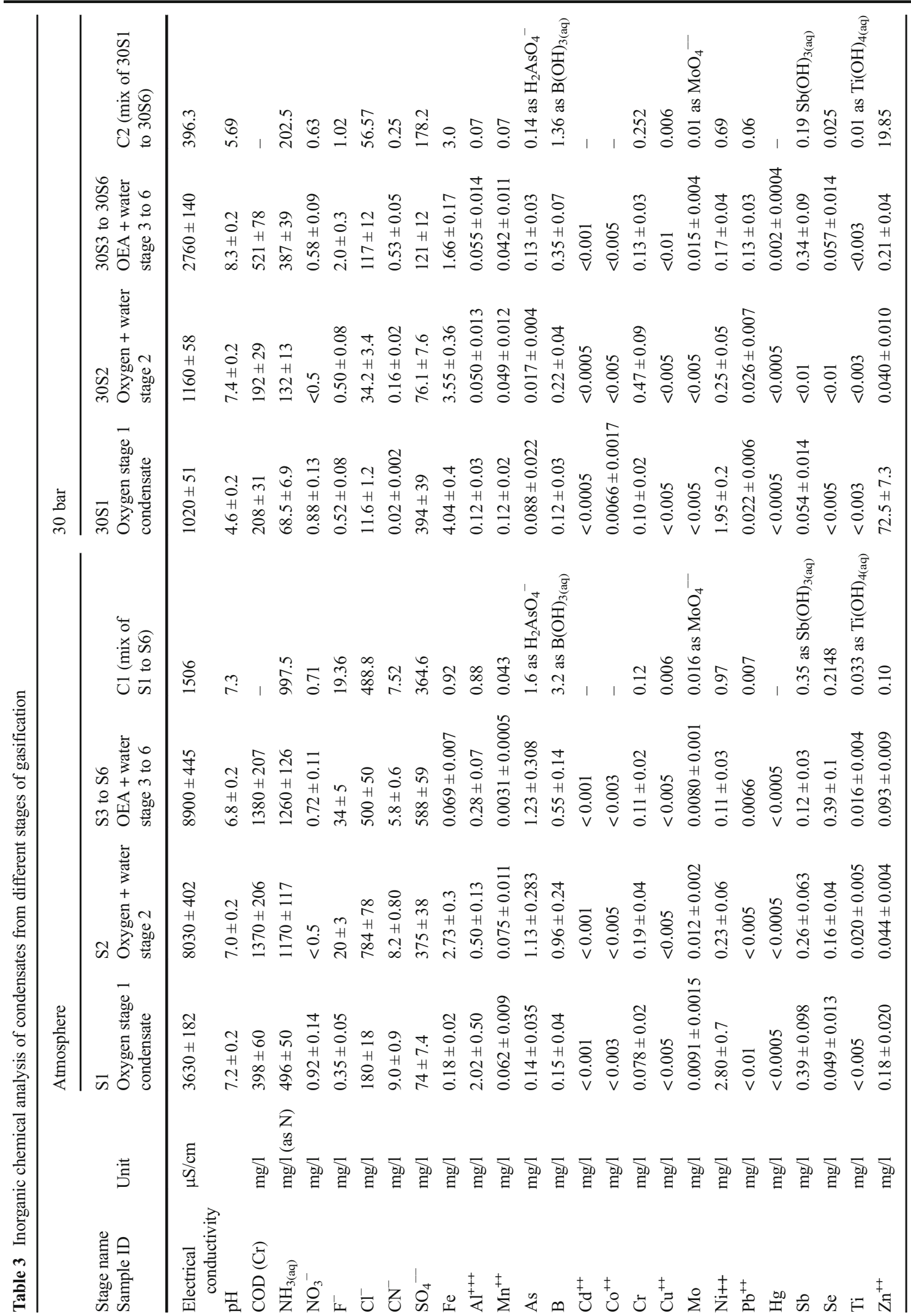


Table 4 Dominant chemical species in the produced water-groundwater system at different $\mathrm{pH}$ values

\begin{tabular}{|c|c|c|c|c|}
\hline \multirow[t]{2}{*}{ Chemical species } & \multirow{2}{*}{$\begin{array}{l}\text { Concentration measured } \\
\text { in the effluent }(\mathrm{mg} / \mathrm{L})\end{array}$} & \multicolumn{3}{|c|}{ Species and concentration at equilibrium with ground water-effluent system } \\
\hline & & pH 3 (mg/kg) & $\mathrm{pH} 7(\mathrm{mg} / \mathrm{kg})$ & $\mathrm{pH} 11(\mathrm{mg} / \mathrm{kg})$ \\
\hline $\mathrm{NH}_{3}{ }^{+}{ }_{(\mathrm{aq})}$ as $\mathrm{N}$ & 997.5 & $\mathrm{~N}_{2(\mathrm{aq})}=957.8$ & $\mathrm{~N} 2_{(\mathrm{aq})}=958.2$ & $\mathrm{~N} 2_{(\mathrm{aq})}=999.6$ \\
\hline $\mathrm{F}^{-}$ & 19.36 & $\begin{array}{l}\mathrm{F}^{-}=8.24 \\
\mathrm{NaF}_{(\mathrm{aq})}=0.029 \\
\mathrm{MgF}^{+}=0.01 \\
\mathrm{Sb}(\mathrm{OH})_{2} \mathrm{~F}_{(\mathrm{aq})}=0.29\end{array}$ & $\begin{array}{l}\mathrm{F}^{-}=17.75 \\
\mathrm{NaF}_{(\mathrm{aq})}=0.029 \\
\mathrm{MgF}^{+}=0.06 \\
\mathrm{Sb}(\mathrm{OH})_{2} \mathrm{~F}_{(\mathrm{aq})}=0.29 \\
\mathrm{CaF}^{+}=0.008\end{array}$ & $\begin{array}{l}\mathrm{F}-=19.06 \\
\mathrm{NaF}_{(\mathrm{aq})}=0.068 \\
\mathrm{MgF}^{+}=0.04 \\
\mathrm{CaF}^{+}=0.009\end{array}$ \\
\hline $\mathrm{CN}^{-}$ & 7.52 & $\mathrm{HCN}_{(\mathrm{aq})}=7.82$ & $\begin{array}{l}\mathrm{HCN}_{(\mathrm{aq})}=7.78 \\
\mathrm{CN}_{(\mathrm{aq})}=0.035\end{array}$ & $\begin{array}{l}\mathrm{HCN}_{(\mathrm{aq})}=0.16 \\
\mathrm{CN}_{(\mathrm{aq})}=7.31\end{array}$ \\
\hline $\mathrm{H}_{2} \mathrm{AsO}_{4}$ & 1.6 & $\begin{array}{l}\text { As }(\mathrm{OH})_{3(\mathrm{aq})}=0.63 \\
\mathrm{HAsO}_{2(\mathrm{aq})}=0.63\end{array}$ & $\begin{array}{l}\mathrm{As}(\mathrm{OH})_{3(\mathrm{aq})}=0.63 \\
\mathrm{HAsO}_{2(\mathrm{aq})}=0.63\end{array}$ & $\begin{array}{l}\mathrm{AsO}_{2} \mathrm{OH}^{-}=0.52 \\
\mathrm{AsO}_{2}-=0.36 \\
\mathrm{H}_{2} \mathrm{AsO}_{3^{-}}=0.42 \\
\mathrm{HAsO}_{4}-=0.05 \\
\mathrm{AsO}_{4}--=0.02 \\
\mathrm{As}^{-}(\mathrm{OH})_{3(\mathrm{aq})}=0.007 \\
\mathrm{HAsO}_{2(\mathrm{aq})}=0.006\end{array}$ \\
\hline $\mathrm{Al}^{3+}$ & 0.93 & $\mathrm{Al}^{+++}=0.91$ & $\mathrm{AlO}_{2}^{-}=1.457$ & $\mathrm{AlO}_{2}^{-}=0.78$ \\
\hline $\mathrm{Fe}^{2+}$ & 0.98 & $\mathrm{Fe}^{++}=0.96$ & $\mathrm{Fe}^{++}=0.97$ & - \\
\hline $\mathrm{Ni}^{2+}$ & 0.97 & $\mathrm{Ni}^{++}=0.90$ & $\mathrm{Ni}^{++}=0.90$ & - \\
\hline $\mathrm{Sb}(\mathrm{OH})_{3(\mathrm{aq})}$ & 0.35 & $\begin{array}{l}\mathrm{Sb}(\mathrm{OH})_{2} \mathrm{~F}_{(\mathrm{aq})}=0.29 \\
\mathrm{Sb}(\mathrm{OH})_{3(\mathrm{aq})}=0.061 \\
\mathrm{Sb}(\mathrm{OH})^{2+}=0.0024\end{array}$ & $\mathrm{Sb}(\mathrm{OH})_{3(\mathrm{aq})}=0.3575$ & $\begin{array}{l}\mathrm{Sb}(\mathrm{OH})_{3(\mathrm{aq})}=0.31 \\
\mathrm{Sb}(\mathrm{OH})_{4}{ }^{-}=0.03\end{array}$ \\
\hline $\mathrm{SeO}_{3}^{-}$ & 0.21 & $\mathrm{Se}_{(\mathrm{s})} \log (\mathrm{Q} / \mathrm{K})=13.5242$ (saturated $)$ & $\mathrm{HSe}^{-}=0.19$ & - \\
\hline $\mathrm{CrO}_{4}^{2-}$ & 0.29 & $\mathrm{Cr}^{+++}=0.1237$ & $\mathrm{Cr}^{+++}=0.12$ & - \\
\hline $\mathrm{B}(\mathrm{OH})_{3(\mathrm{aq})}$ & 3.2 & $\mathrm{~B}(\mathrm{OH})_{3(\mathrm{aq})}=3.1$ & $\mathrm{~B}(\mathrm{OH})_{3(\mathrm{aq})}=3.1$ & $\mathrm{~B}(\mathrm{OH})_{3(\mathrm{aq})}=0.056$ \\
\hline
\end{tabular}

condensate at high-pressure stages had an influence on the metal ions such as $\mathrm{Zn}$, which is relatively higher in stage $\mathrm{S} 1$. Trace elements such as $\mathrm{Sb}$ and Se were also found in the condensates at maximum concentration levels of $0.39 \mathrm{mg} / \mathrm{L}$. Most of the measured concentration levels exceed the legal limits for disposal. For example, the $\mathrm{BOD}, \mathrm{COD}$ and ammonia nitrogen concentrations were much higher than the legal limits $(B O D=50 \mathrm{mg} / \mathrm{L}$ $\mathrm{O}_{2}$ and $250 \mathrm{mg} / \mathrm{L} \mathrm{O}_{2}$ : Urban Wastewater Treatment (England and Wales) Regulations 1994). So appropriate treatment methods need to be explored to treat the effluent generated by cleaning the gas.

The samples $\mathrm{Cl}$ (for atmospheric experiments) and C2 (for high-pressure experiments) in Table 3 show the calculated concentrations. The calculation was carried out by theoretically mixing the samples at appropriate mass ratios as described in Hounslow (1995). For example, S1, S2 and S3 to S6 were mixed at the proportions of $545 \mathrm{~kg}: 773 \mathrm{~kg}: 684 \mathrm{~kg}$. The concentration levels of contamination presented in this work were measured in the produced water (water injected + water used for cleaning the gas). Under the relevant assumption that the similar level of concentrations can escape through fissures and end up in groundwater, the concentrations from the experiments were used to calculate the equilibrium species concentrations in the event of contaminants ending up in the groundwaters found in the deep coal seams. The concentrations of the species in sample $\mathrm{C} 1$ and $\mathrm{a} \cong$ $600 \mathrm{~m}$ deep coal seam water from the South Wales Coalfield (concentrations of major ions in the coal seam aquifer: $\mathrm{Na}=540 \mathrm{mg} / \mathrm{L}, \mathrm{K}=10.03 \mathrm{mg} / \mathrm{L}, \mathrm{Mg}=1.29 \mathrm{mg} /$ $\mathrm{L}$ and $\mathrm{Ca}=2.87 \mathrm{mg} / \mathrm{L}$, dissolved oxygen $=2.25 \mathrm{mg} / \mathrm{L}$; Sadasivam et al. 2019) were used in the calculation to predict the dominant species (GWB method has been provided in the supplementary information). Table 4 shows the main aqueous species and concentrations of $\mathrm{NH}^{+}, \mathrm{F}^{-}, \mathrm{Cl}^{-}, \mathrm{CN}^{-}, \mathrm{SO}_{4}{ }^{2-}, \mathrm{Fe}^{2+}, \mathrm{Al}^{3+}, \mathrm{Mn}^{2+}, \mathrm{As}, \mathrm{Ni}, \mathrm{Pb}$, $\mathrm{Sb}(\mathrm{OH})_{3}$ and $\mathrm{SeO}_{3}{ }^{2-}$ at $\mathrm{pH}$ values of 3,7 and 11. For example, most of the ammonium species would disassociate to release $\mathrm{N}_{2 \text { (aq) }}$ and the toxic $\mathrm{HCN}^{-}$would be the more dominant cyanide species at neutral $\mathrm{pH}$ values and below. The dominant species along with the overburden 


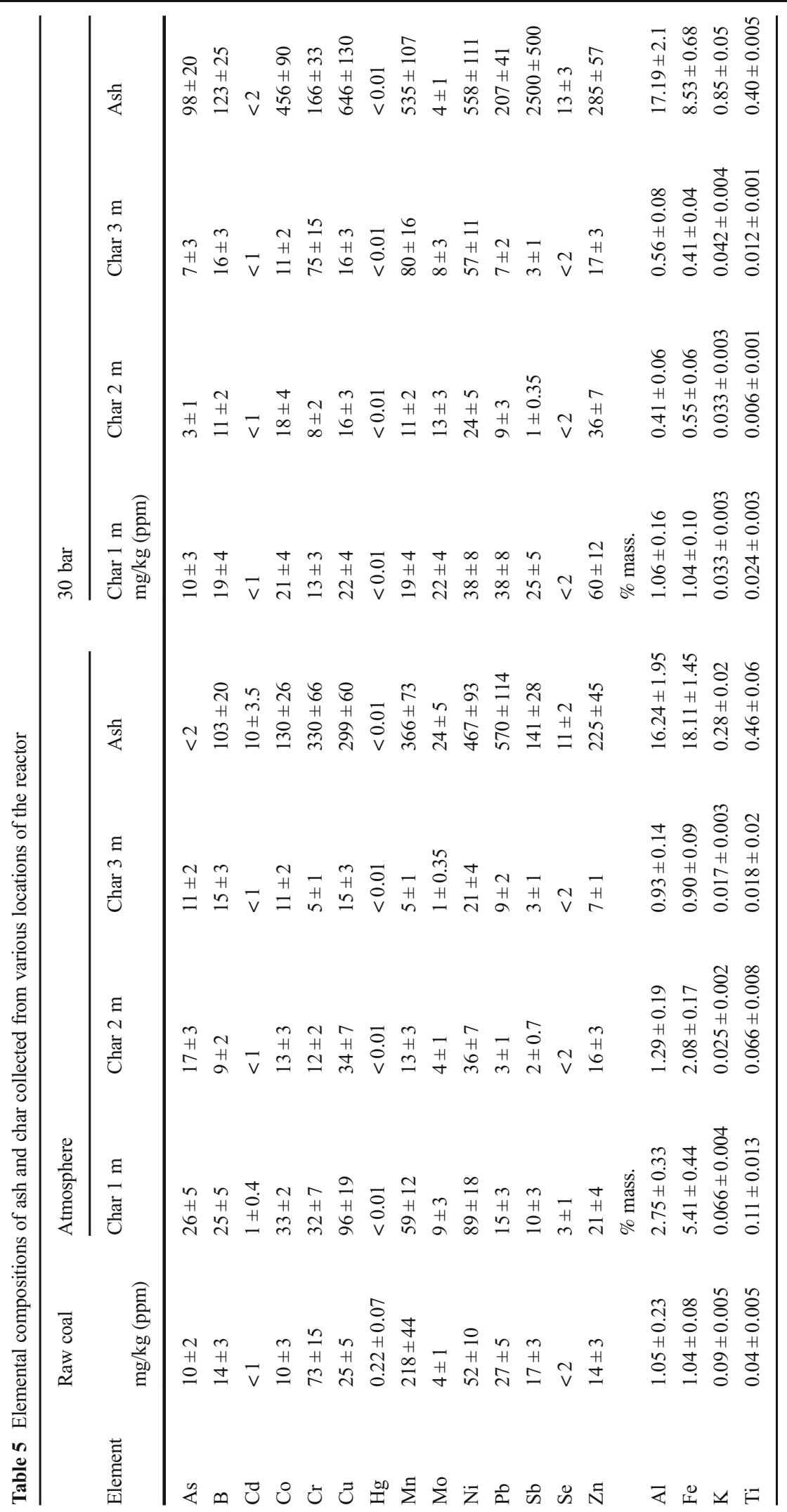


geology must be studied experimentally for their transportation and bio-geo-transformation to understand their natural restoration process.

Figure 2 shows the images of both ends of the coal seam after the experiment, demonstrating that the coal has been almost entirely gasified near the inlet, while a substantial amount of unreacted char was left near the outlet of the reactor. Table 5 shows the elemental composition of the raw coal, ash and char samples taken from different locations of the reactor during the atmospheric and elevated (30 bar) pressure experiments (Fig. 2). Al, Fe, K and Ti were the major constituents of the ash and char (Table 5). The inorganic elements, which are usually influenced by the groundwater $\mathrm{pH}$, were predominant in the ash. The iron content in the ash was around $18 \%$. The concentrations of chemical species indicate that the ash and char left in the cavity might be a source of secondary contaminations or can act as an adsorbent for the other inorganics species that have an affinity towards iron oxide surfaces. The iron left in the reactor or in the UCG cavity might be in the form of haematite due to the exposure of the elevated temperature. So, a theoretical ratio of $5 \mathrm{~g}$ of haematite to $1 \mathrm{~kg}$ of water was used to predict the sorbed fractions for the species of arsenic, boron, calcium, cobalt, chromium, copper, nickel, lead and selenium. The surface complexation reactions from Dzombak and Morel (1990) along with the extended database from GWB application software were used to predict the sorbed fractions. The sorbed fractions of chemical species on the iron hydroxide surfaces at various $\mathrm{pH}$ are shown in Fig. 3 (GWB method has been provided in Section 2.2 (ii) and supplementary information). The oxyanion of arsenic showed the maximum adsorption in between $\mathrm{pH}$ values of 6 and 9.5. The sorption behaviour of oxyanions of arsenic and selenium can be explained by the specific adsorption of the ligands at the $\mathrm{FeOH}^{+}$and $\mathrm{FeOH}^{0}$ sites. The high sorption of oxyanions above the point of zero net proton charge of haematite ( $\mathrm{pH} \cong 8.5$ ) can be explained by their covalent nature of the sorption. The selenite ions would be retained on the iron oxide surface as ligands by replacing the hydroxyl ions at lower $\mathrm{pH}$ values. Chromate ion sorption shows the pattern of chromate ions binding on the already sorbed cations and anions whereas other cations such as $\mathrm{Cu}, \mathrm{Ni}$ and $\mathrm{Pb}$ show the pattern of specific sorption by deprotonating the surface hydroxyl group (Zelazny et al. 2018; Su and Suarez 2000; Cornell and Schwertmann 2004).

Table 6 shows a quantitative evaluation of the sorption pattern showed in Fig. 3. At $\mathrm{pH}$ values around 4, $\mathrm{As}(\mathrm{OH})_{4}$ concentration in the original fluid was $2.25 \times$ $10^{-3}$ moles. After equilibrating with the haematite mineral $2.17 \times 10^{-3}$ moles were adsorbed on the weak surfaces $(w)$ as $\mathrm{FeOHAsOH}{ }^{3-}\left(1.1 \times 10^{-3}\right.$ moles $)$, $\mathrm{FeHAsO}_{4}{ }^{-}\left(8.9 \times 10^{-4}\right.$ moles $)$ and $\mathrm{FeH}_{2} \mathrm{AsO}_{4}(1.7 \times$ $10^{-4}$ moles $)$. The $\mathrm{B}(\mathrm{OH})_{3}$ with an initial concentration of $5.5 \times 10^{-5}$ moles were adsorbed as $\mathrm{FeH}_{2} \mathrm{BO}_{3}(3.39 \times$ $10^{-7}$ moles) at $\mathrm{pH}$ values around 4 . Arsenic showed similar pattern at $\mathrm{pH}$ values around 8.3 , but the boron sorption reduced (adsorbed as $\mathrm{B}(\mathrm{OH})_{3}=9.7 \times$ $10^{-7}$ moles) as the positive charge sites originated from the protonated surfaces started disappearing at $\mathrm{pH}$ values around 8 . Similarly, nickel and copper quantitative sorbed fractions were presented in Table 1. At $\mathrm{pH} 4$, $3.2 \times 10^{-7}$ moles of $\mathrm{Ni}$ would be retained on the strong surfaces $(s)$ as $\mathrm{FeONi}^{+}$. The sorbed fraction increases as the $\mathrm{pH}$ increases to 8.3 where $1.8 \times 10^{-3}$ moles would be
Fig. 3 Sorbed fractions of some species on iron surfaces

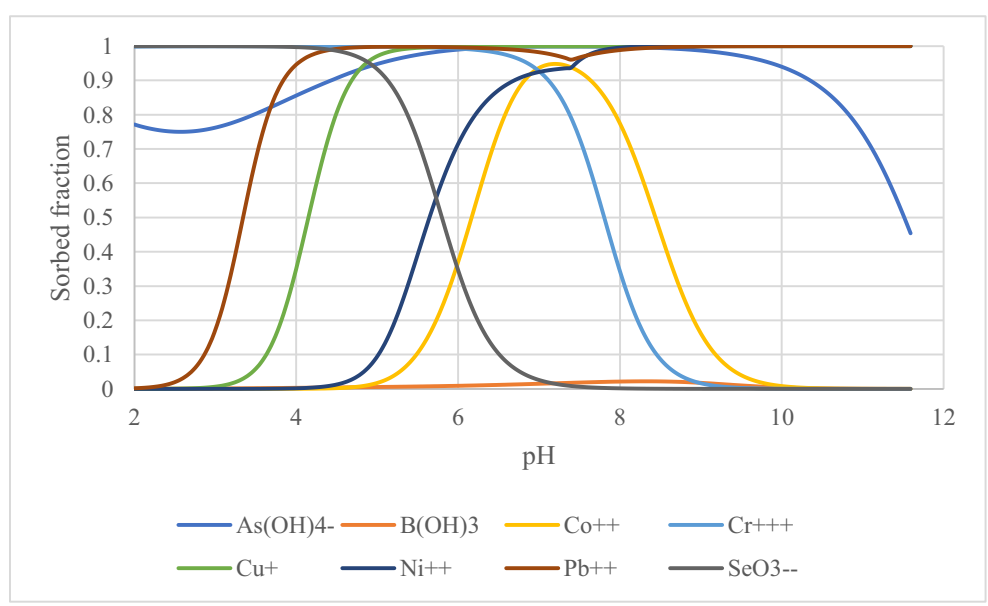




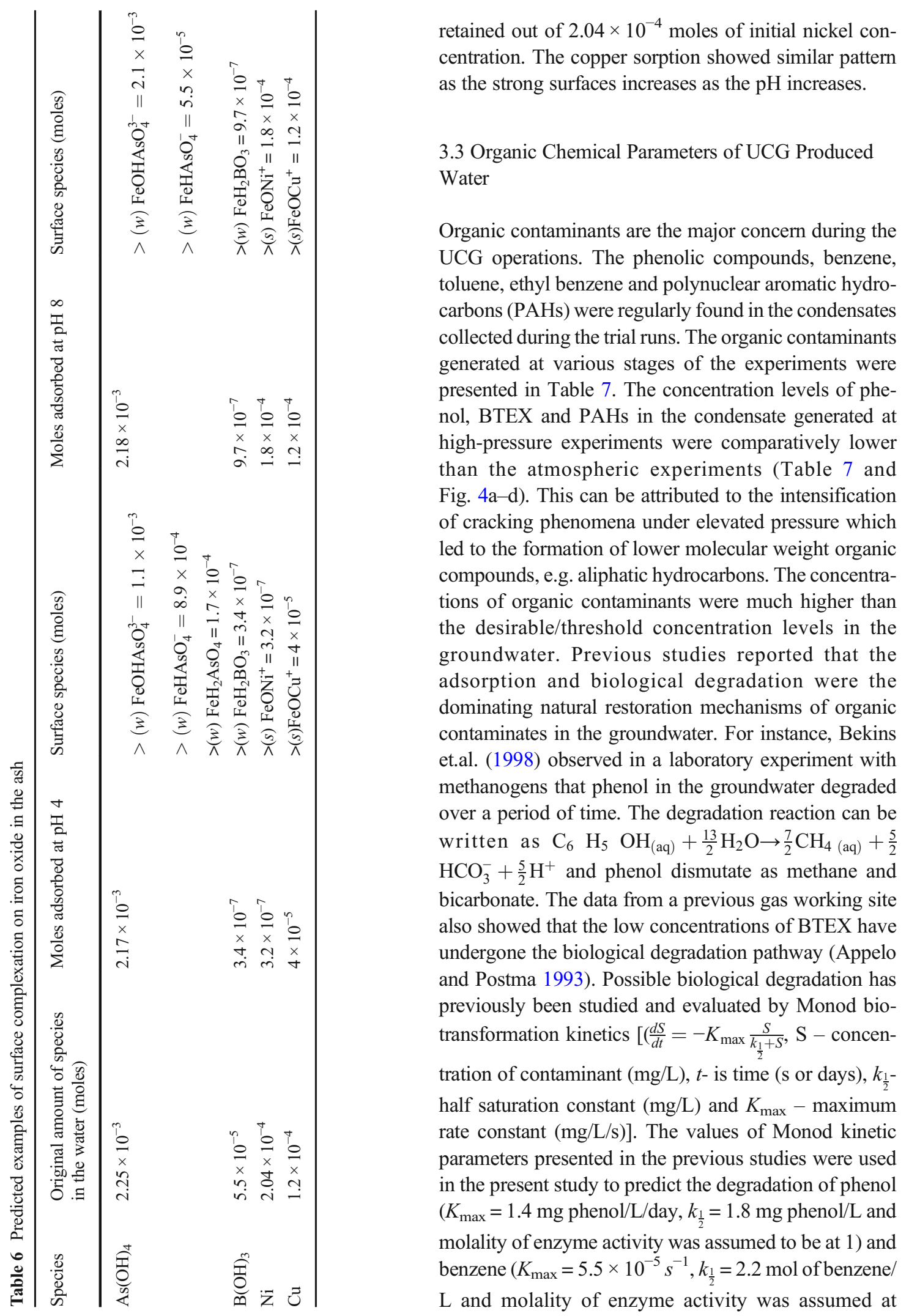




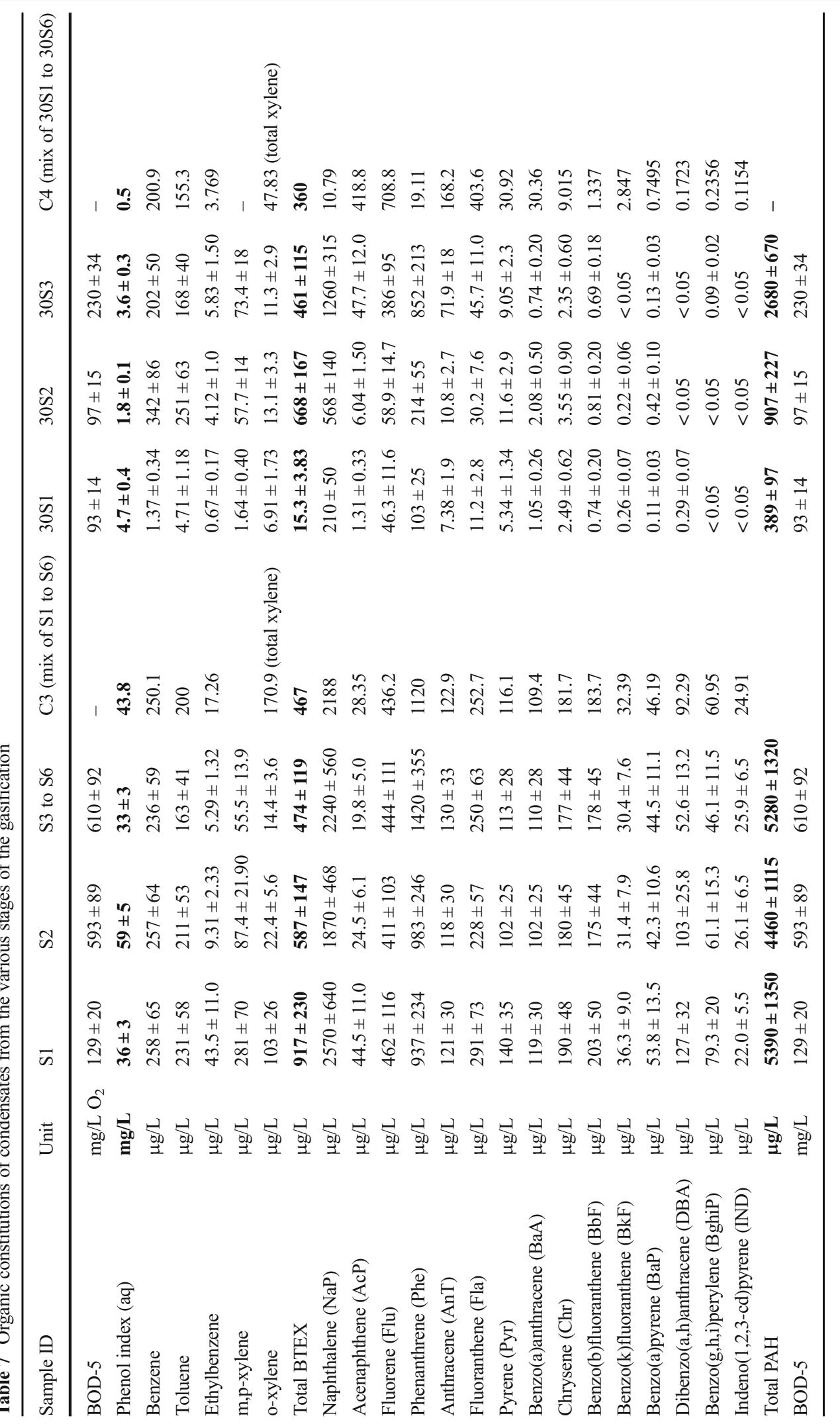




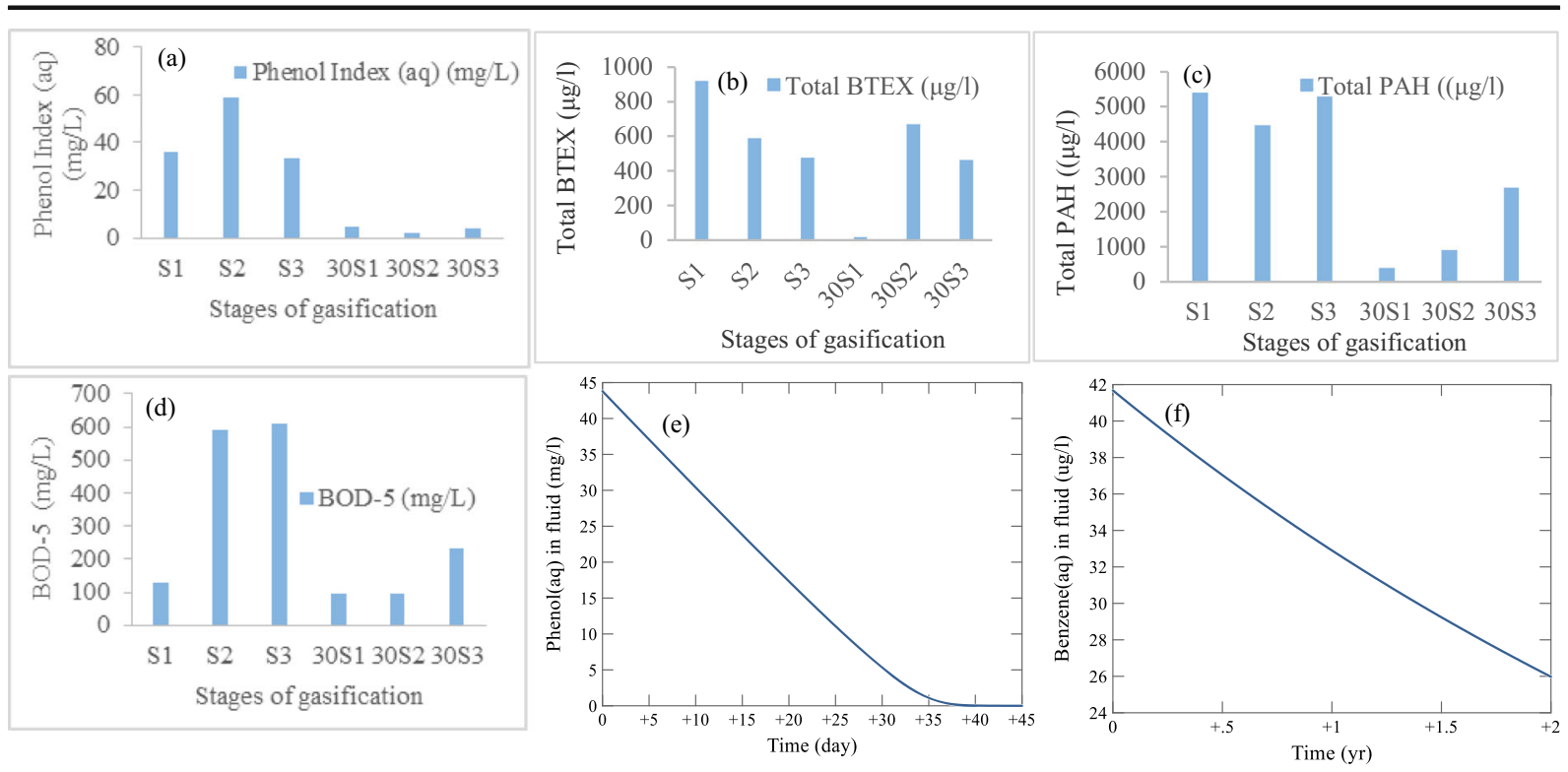

Fig. 4 a-d Comparison of organic parameters measured in the condensates at various stages of the gasification; e microbial methanogenic degradation from UCG contaminate groundwater,

0.001). (Alvarez et al. 1991; Appelo and Postma 1993). Concentrations of major ions from $\mathrm{a} \cong 600 \mathrm{~m}$ deep coal seam aquifer, inorganic constitutions from sample $\mathrm{C} 1$ (Table 3), phenol and benzene concentrations from $\mathrm{C} 3$ (Table 7) were used in the calculations to develop the hypothetical groundwater (See the supplementary information for GWB method and Section 2.2 (iii)). The results show that the possible microbial enhanced natural degradation process reduces the phenol concentration exponentially in 45 days in presence of microbes (Fig. 4e). As the degradation process takes longer even at optimum conditions, the migration and transformation process without or along with enzyme activity needs to be studied. For benzene, the degradation process takes much longer and seems exponential for the literature values provided for the enzyme activity (Fig. 4f). So, the transport and natural restoration of organic contaminations must be studied experimentally at laboratory scale in the framework of UCG.

\section{Conclusions}

This study provided a comprehensive understanding of the quantitative aspects of water balance, contaminant generation at various experimental conditions and their fate in the groundwater environment in the context of f microbial degradation of benzene (calculated using Monod kinetic parameters available in literature)

UCG using high-rank coal. Based on the results obtained, the following conclusions can be made:

i). UCG operational procedures play a major role in contaminants' generation. The overall water balances were maintained during the oxygen, air and OEA driven gasification experiments, both under atmospheric and high-pressure conditions. This suggests that small or negligible amount of condensate may be produced under such conditions, owing to the limited water content of the high-rank coal. Where oxygen and steam were used as oxidants under high-pressure regime, conditions that support high methane generation were established resulting in negative water balance.

ii). Maintaining high operating pressure would influence and prevent high-level contaminant generation. The contaminants generated were moderately low in concentrations during the 30-bar pressure experiment (especially the inorganic contaminants and organic contaminants such as phenol and PAHs), but not applied to all kinds of contaminants produced, such as BTEX. In the event of contaminant escape, the dominant species' concentrations measured in the study would be useful to predict the contaminant spread. Notably, high concentrations of dissolved ammonia nitrogen, hydrogen cyanide and fluoride species showed dominance 
along with other metal and metalloid species at varying $\mathrm{pH}$ range.

iii). $\mathrm{Al}, \mathrm{Fe}, \mathrm{K}$ and $\mathrm{Ti}$ were the major elements present in the residual ash and char generated at both atmospheric and elevated pressure conditions. The surface complexation calculations for the sorbed fractions of the inorganic species on iron oxide indicated the ash left in the cavity is a potential sorbent. Previously reported possible biodegradation of organic contaminants has been evaluated with the actual concentrations produced in the study which showed that the reduction in phenol concentration takes 45 days and benzene takes more than 2 years. However, the contaminant concentration levels produced in the present study must be studied at laboratory scale to reliably predict the sorption/transport/ biotransformation of the contaminations for given field conditions.

Overall, the study provided novel insights on the contaminant generation during gasification of a highrank coal and the results produced would significantly benefit the site selection in the aspect of contaminant spread and the selection of gas cleaning and water treatment options.

Acknowledgements This work was carried out as a part of the FLEXIS project which has been part-funded by the European Regional Development Fund through the Welsh Government. The financial support, for the first two authors, is gratefully acknowledged.

Open Access This article is licensed under a Creative Commons Attribution 4.0 International License, which permits use, sharing, adaptation, distribution and reproduction in any medium or format, as long as you give appropriate credit to the original author(s) and the source, provide a link to the Creative Commons licence, and indicate if changes were made. The images or other third party material in this article are included in the article's Creative Commons licence, unless indicated otherwise in a credit line to the material. If material is not included in the article's Creative Commons licence and your intended use is not permitted by statutory regulation or exceeds the permitted use, you will need to obtain permission directly from the copyright holder. To view a copy of this licence, visit http://creativecommons.org/licenses/by/4.0/.

\section{References}

AER. (2014). AER investigation report. Swan Hills Synfuels ltd., well blowout, 10 October 2011. Calgary: Alberta Energy Regulator.
Alvarez, P. J. J., Anid, P. J., \& Vogel, T. M. (1991). Kinetics of aerobic biodegradation of benzene and toluene in sandy aquifer material. Biodegradation, 2, 43-51. https://doi. org/10.1007/BF00122424.

Appelo C.A.J. and Postma D., 1993, Geochemistry, groundwater and pollution, A.A. Balkema, Rotterdam, 489-540.

ASTM D388-18a. (2018). Standard classification of coals by rank. West Conshohocken, PA: ASTM International. https://doi.org/10.1520/D0388-18A.

ASTM International D3176-15. (2015). Standard Practice for Ultimate Analysis of Coal and Coke. West Conshohocken: ASTM International. https://doi.org/10.1520/D3176-15.

ASTM International D7582-15. (2015). Standard Test Methods for Proximate Analysis of Coal and Coke by Macro Thermogravimetric Analysis. West Conshohocken: ASTM International. https://doi.org/10.1520/D7582-15.

Australian government's environmental protection notice 2016 (https://apps.des.qld.gov.au/enforcement-tools/pdf/stat1111. pdf). Accessed 2019-2020.

Bekins, B.A., Warren E. and Godsy, E.M. (1998) A Comparison of Zero-Order, First-Order, and Monod Biotransformation Models. Ground Water, 36(2):261-268.

Bethke, C.M. Geochemical and Biogeochemical Reaction Modelling Second Edition. (2007). Cambridge University press. Cambridge: UK.

Blinderman, M. S., \& Jones, R. M. (2002). The Chinchilla IGCC project to date: UCG and environment, 2002 gasification technologies conference. San Francisco, 2002 https://www. globalsyngas.org/uploads/eventLibrary/GTC02043.pdf. Accessed 2019-2020.

Campbell, J. H., Wang, F. T., Mead, S. W., \& Busby, J. F. (1979). Groundwater quality near an underground coal gasification experiment. Journal of Hydrology, 44, 241-266. https://doi. org/10.1016/0022-1694(79)90134-3.

Cornell, R.M., Schwertmann, U. (2004). Adsorption of ions and molecules. In the Iron oxides (eds R.M. Cornell and U. Schwertmann), doi:https://doi.org/10.1002/3527602097. ch11.

Covell, J. R. and Thomas, M. H., 1996, Combined air Sparging and bioremediation of an underground coal gasification site. EG\&G Report DE-AC21-95MC31346.

Creedy DP, Garner, K, Holloway, S, Jones, N and Ren, TX (2001) Review of underground COAL gasification technological advancements. Report no. COAL R211, DTI/pub URN 01/ 1041. DTI/crown copyright. (BGS, Nottingham University and Wardell Armstrong) https://www.cluffnaturalresources. com/wp-content/uploads/2016/01/2001-Review-of-UCGTechnological-Advancements.pdf. Accessed 2019-2020.

Dames and Moore 1996. Final project summary report drill and sample monitoring wells for remediation at hoe creek UCG site, Campbell County, Wyoming. Job \# 13474-021-030. March 27, 1996.

Dzombak, D. A., \& Morel, F. M. M. (1990). Surface complexation modeling: Hydrous ferric oxide. New York: John Wiley \& Sons.

Gemmell C., (Rev.). (2016). Independent Review of Underground Coal Gasification- Report. https://www.gov. scot/binaries/content/documents/govscot/publications/ independent-report/2016/10/independent-reviewunderground-coal-gasification-report/documents/00507473- 
pdf/00507473-pdf/govscot\%3Adocument/00507473.pdf. Accessed 2019-2020.

Geology and Regional Geophysics Commissioned Report CR/13/ 142. (2013). A study of potential unconventional gas resource in Wales. Nottingham: British Geological Survey Keyworth https://gov.wales/sites/default/files/publications/2019-06 /potential-unconventional-gas-resource-in-wales.pdf.

Hounslow, A. W. (1995). Water quality data: Analysis and interpretation (pp. 110-111). Boca Raton: CRC Press.

Humenick, M. J., \& Mattox, C. F. (1978). Groundwater pollutants from underground coal gasification. Water Research, 12, 463-469. https://doi.org/10.1016/0043-1354(78)90153-7.

Humenick, M. J., \& Novak, A. E. (1978). Parametric analysis of pollutant migration following in situ gasification of lignite. In Situ, 2, 329-352.

ISO/TS 13605:2012 Solid mineral fuels - Major and minor elements in hard coal ash and coke ash - Wavelength dispersive X-ray fluorescence spectrometric method. ISO 13605:2018, https://www.iso.org/obp/ui/\#iso:std:iso:13605:ed-1:v1:en. Accessed 2019-2020.

Kapusta, K., \& Stańczyk, K. (2011). Pollution of water during underground coal gasification of hard coal and lignite. Fuel, 90, 1927-1934. https://doi.org/10.1016/j.fuel.2010.11.025.

Kapusta, K., Stańczyk, K., Wiatowski, M., \& Chećko, J. (2013). Environmental aspects of a field-scale underground coal gasification trial in a shallow coal seam at the experimental mine Barbara in Poland. Fuel, 113, 196-208. https://doi. org/10.1016/j.fuel.2013.05.015.

Liu, S., Li, J., Mei, M., \& Dong, D. (2007). Groundwater pollution from underground coal gasification. Journal of China University of Mining and Technology, 17, 467-472. https://doi.org/10.1016/S1006-1266(07)60127-8.

PN-EN 1899-1:2002 Water Quality - Determination of Biological Oxygen Demand after $\mathrm{n}$ days $(\mathrm{BODn})=$ Part 1: Dilution and vaccination with allyl thiourea method. BS EN ISO 5815-1: 2019, ISO 5815-1:2019, https://www.iso. org/obp/ui/\#iso:std:iso:5815:-1:ed-2:v1:en. Accessed 20192020.

PN-EN 1899-2:2002 Water Quality - Determination of Biological Oxygen Demand after $\mathrm{n}$ days $(\mathrm{BODn})=$ Part 2: Method for undiluted samples. BS EN 1899-2:1998, BS 6068-2.64: 1998, https://www.iso.org/obp/ui/\#iso:std:iso:5815:-2:ed1:v1:en. Accessed 2019-2020.

PN-EN ISO 11732:2007. Water quality - Determination of ammonium nitrogen - Method by flow analysis (CFA and FIA) and spectrometric detection. BS EN ISO 11732:2005, BS 6068-2.93:2005, ISO 11732:2005, https://www.iso. org/obp/ui/\#iso:std:iso:11732:ed-2:v1:en. Accessed 20192020.

PN-EN ISO 11885:2009. Water quality — Determination of selected elements by inductively coupled plasma optical emission spectrometry (ICP-OES). BS EN ISO 11885:2009, https://www.iso.org/obp/ui/\#iso:std:iso:11885:ed-2:v1:en. Accessed 2019-2020.

PN-EN ISO 14402:2004. Water quality - Determination of phenol index by flow analysis (FIA and CFA). International equivalents: BS EN ISO 14402:1999, BS 6068-2.68:1999, https://www.iso.org/obp/ui/\#iso:std:iso:14402:ed-1:v1:en. Accessed 2019-2020.

PN-EN ISO 14403:2004. Water quality - Determination of total cyanide and free cyanide by continuous flow analysis. BS EN I S O 14403-1:2012, https://w w w i s o. org/obp/ui/\#iso:std:iso:14403:-2:ed-1:v1:en. Accessed 2019-2020.

PN-ISO 15705:2005 Water Quality - Determination of the chemical oxygen demand index (COD) - The miniaturized method with sealed tubes. https:// www.iso. org/obp/ui/\#iso:std:iso:15705:ed-1:v1:en. Accessed 20192020.

Sadasivam, S., Thomas, H. R., Zagorscak, R., Davies, T., \& Price, N. (2019). Baseline geochemical study of the Aberpergwm mining site in the South Wales coalfield. J. Geochemical Explor. https://doi.org/10.1016/j.gexplo.2019.03.006.

Stephens, D. R. (1981). The hoe creek experiments: LLNL's underground coal gasification project in Wyoming. Livermore: Lawrence Livermore National Laboratory UCRL-53211.

Su, C., \& Suarez, D. L. (2000). Selenate and selenite sorption on iron oxides an infrared and electrophoretic study. Soil Science Society of America Journal, 64, 101-111. https://doi.org/10.2136/sssaj2000.641101x.

Sury M, White M, Kirton J, Carr P and Woodbridge R, 2004. Review of environmental issues of underground COAL gasification. Report no. COAL R272 DTI/pub URN 04/1880, 2004. Page 27-28.

Swan Hills Synfuels, L. P. (2012). Swan Hills in-situ coal gasification technology development-Final outcomes report. Alberta: Swan Hills Synfuels LP.

The Urban Waste Water Treatment (England and Wales) Regulations 1994, http://www.legislation.gov.uk/uksi/1994 /2841/made/data.pdf. Accessed 2019-2020.

Wang, F. T., Mead, S. W., \& Stuermer, D. H. (1982). Mechanisms for groundwater contamination by UCG - preliminary conclusions from the hoe creek site. Livermore: Lawrence Livermore National Laboratory UCRL-88012.

Wiatowski, M., Kapusta, K., Stańczyk, K., \& Stańczyk, K. (2019). Efficiency assessment of underground gasification of orthoand meta-lignite: High-pressure ex situ experimental simulations. Fuel, 236, 221-227. https://doi.org/10.1016/j. fuel.2018.08.143.

Zagorščak, R., Sadasivam, S., Thomas, H. R., Stańczyk, K., \& Kapusta, K. (2020). Experimental study of underground coal gasification (UCG) of a high-rank coal using atmospheric and high-pressure conditions in an ex-situ reactor. Fuel, 270. https://doi.org/10.1016/j.fuel.2020.117490.

Zelazny, L.W., He, L. and Vanwormhoudt, A. (2018). Charge analysis of soils and anion exchange. In methods of soil analysis (eds D. Sparks, A. page, P. Helmke, R. Loeppert, P.N. Soltanpour, M.a. Tabatabai, C.T. Johnston and M.E. Sumner). https://doi.org/10.2136/sssabookser5.3.c41.

Publisher's Note Springer Nature remains neutral with regard to jurisdictional claims in published maps and institutional affiliations. 